\title{
Jakub Bobrowski \\ Archaizmy leksykalne jako ewokanty dawności kulturowej i językowej w idiolekcie pisarskim Stanisława Wyspiańskiego. Analiza semantyczna i stylistyczno-funkcjonalna Wydawnictwo Libron, Kraków 2015, ss. 398
}

Wydana w 2015 r. książka J. Bobrowskiego powstała w ramach projektu badawczego "Słownictwo dyferencjalne w dramatach Stanisława Wyspiańskiego - studia leksykologiczno-leksykograficzne" realizowanego w latach 2012-2016 ze środków Narodowego Programu Rozwoju Humanistyki. Warto nadmienić, że wstępna wersja monografii została przedstawiona jako rozprawa doktorska na Wydziale Polonistyki Uniwersytetu Jagiellońskiego już w roku 2012. Deklarowanym przez autora celem pracy, poza oczywistym walorem poznawczym, jest umożliwienie czytelnikom dzieł Wyspiańskiego pokonania pewnej bariery $\mathrm{w}$ procesie odbioru i rozumienia tekstu literackiego. Barierą tą autor nazywa wszelkiego rodzaju osobliwości językowe. Tym samym monografia miałaby stać się praktyczną pomocą dla wydawców, tłumaczy, historyków literatury, nauczycieli a także inscenizatorów dramatów Stanisława Wyspiańskiego.

Praca składa się z dwóch głównych części: teoretyczno-opisowej (Zatożenia teoretyczne i Opis semantyczny $i$ stylistyczno-funkcjonalny archaizmów w jezyku Stanisława Wyspiańskiego) oraz słownikowej (Słownik tematyczny archaizmów rzeczowych i Słownik archaizmów stylistycznych). Bazę materiałową do przeprowadzenia badań stanowiły teksty dramatyczne Wyspiańskiego będące główną częścią jego twórczości. Wszystkie poddane analizie teksty pochodziły z wydania krytycznego Dzieł zebranych Stanisława Wyspiańskiego z lat 1958-1971 (Wydawnictwo Literackie). Monografia skupia się na idiolekcie pisarza i stanowi wyczerpujące opracowanie 
archaizmów występujących w jego twórczości - stąd można uznać ją za pracę nie tylko literaturoznawczą, ale i socjolingwistyczną.

Na początku swojej książki autor przybliża czytelnikom zagadnienie języka artystycznego i umiejscawia w jego obrębie subidiolekt pisarski Stanisława Wyspiańskiego. Przypomina, że analizowanie języka poszczególnych autorów stanowi punkt wyjścia do badania szerszych zjawisk, takich jak np. przemiany norm gramatycznych czy nastrojów społecznych $\mathrm{w}$ danym czasie. $W$ dalszej kolejności omówiony zostaje język dramatu jako problem badawczy: specyfika utworów scenicznych polega na tym, że są one swoistym amalgamatem różnych gatunków literackich, a nierzadko i języka potocznego. Dodatkowo sama struktura dramatu otwiera badaczom szerokie pole do analizy na wielu poziomach, np. funkcjonalnym, semiotycznym, strukturalnym. Następnie autor skupia się na pojęciu archaizmu i wydziela dwie kategorie, którymi będzie operował w dalszej części monografii: archaizmy rzeczowe - przywołujące desygnaty odległe poznawczo w aspekcie czasowym dla czytelnika oraz archaizmy stylistyczne - będące archaicznymi odpowiednikami jednostek współcześnie używanych. Kolejne podrozdziały zostały poświęcone opisowi stanu badań: w pierwszej kolejności nad archaizmami w tekstach literackich, następnie nad językiem (idiolektem) Stanisława Wyspiańskiego. Największy objętościowo podrozdział pierwszej części omawianej monografii stanowi Metodologia opisu archaizmów leksykalnych w subidiolekcie pisarskim Stanisława Wyspiańskiego. Autor przedstawia tu własne pomysły teoretyczne na realizację tematu swojej pracy. Przybliżone zostają trzy najważniejsze zagadnienia: sposoby identyfikacji i ekscerpcji archaicznego zasobu leksykalnego z tekstów dramatycznych Wyspiańskiego, zasady opisu słownikowego poszczególnych jednostek oraz zakres i cel interpretacji stylistycznej zgromadzonego materiału. Autor postawił na analizę kontrastywną, przyjmując za normę młodopolskiej polszczyzny materiał słownikowy z przełomu XIX i XX wieku, choć do takiego rozwiązania sam podchodzi z dozą ostrożności. Dalej omawiane są narzędzia i teorie, które zostały wykorzystane do przeprowadzenia przez Bobrowskiego własnych badań, m.in.: teoria pól semantycznych, fasety, gramatyka generatywna. Po przedstawieniu metodologii Bobrowski porusza jeszcze jedną kwestię, mianowicie dookreśla, jak traktowana będzie w jego badaniach kategoria pisarza: w związku z podjętym szczegółowym opisem idiolektu Wyspiańskiego, autor odwoływać się będzie do jego instancji nadawczej. 
Szczegółowa charakterystyka archaizmów występujących w dramatach Wyspiańskiego zostaje rozpoczęta od sporządzenia klasyfikacji archaizmów rzeczowych. Autor podzielił tę grupę na tematy i przedstawił jako osiem pól leksykalno-semantycznych: 1) postacie z przeszłości, 2) ludy historyczne, 3) miejsca wypadków dziejowych, 4) życie codzienne i obyczaje, 5) wojna $i$ wojskowość, 6) życie społeczne, 7) wierzenia, 8) sztuka $i$ wiedza. Zdaniem autora taki podział odzwierciedla obraz świata przeszłości wykreowany przez Wyspiańskiego w dramatach. W dalszej kolejności dokonano podziału poszczególnych pól tematycznych na subklasy, nawiązując do semantyki rozumienia. I tak, dla przykładu, dla pola tematycznego 6) życie społeczne - wyróżniono następujące subklasy: 6.1) stosunki społeczne, 6.2) urzędy i urzędnicy, 6.3) stużba, 6.4) sądownictwo, 6.5) powinności i podatki, 6.6) tytuły grzecznościowe.

Po dokonaniu ogólnego opisu rozwarstwienia tematycznego archaizmów rzeczowych, autor rozpoczyna szczegółowe omówienie każdego z pól leksykalnych. Podaje liczebność archaizmów rzeczowych w każdej z subklas - nasycenie leksemami, przedstawia profilowanie poszczególnych archaizmów przy pomocy faset, a także omawia najczęstsze połączenia wyrazowe w obrębie danego pola. Wśród najważniejszych wniosków na temat językowej wizji przeszłości w idiolekcie pisarskim Stanisława Wyspiańskiego badacz wymienia: umiejscowienie historii Polski w centrum zainteresowań pisarza, bogactwo odniesień do wojny i wojskowości, jak również do sfery religijnej (wierzenia antyczne w przewadze nad słowiańskimi) oraz duże zróżnicowanie pod względem pól syntagmatycznych lub kolokacyjnych archaizmów rzeczowych. Ponadto autor zwraca uwagę na szczególnego rodzaju trudność w odbiorze dramatów Wyspiańskiego nadaną z zamysłem pisarza, co ma świadczyć nie tylko o erudycji czwartego wieszcza, ale także o świetnej orientacji we współczesnych sobie badaniach historycznych i prowadzonych na ten temat sporach. Kolejnym punktem analizy jest zbadanie stopnia nasycenia poszczególnych dramatów archaizmami rzeczowymi. Poza statystyką, autor powołuje się $\mathrm{w}$ tej części na typologię podstawowych funkcji archaizmów S. Dubisza. Najważniejszą rolę w badanym materiale odgrywają funkcje fabularne: funkcja chronologizująca, lokalizacyjna, etniczna, ideowa, odrealniająca; poza tym archaizmy mogą pełnić też funkcję charakteryzującą bohatera literackiego. Warto zwrócić jeszcze uwagę na dodatkową perspektywę zastosowaną przez Bobrowskiego w profilowaniu poszczególnych leksemów, mianowicie na perspektywę 
intertekstualną. Do tekstów źródłowych autor zaliczył: Biblię, eposy Homera, dramaty Sofoklesa, polskie kroniki średniowieczne, Makbeta Szekspira, Konrada Wallenroda Mickiewicza, pieśń Warszawianka 1831 roku i osiemnastowieczną piosenkę Kurdesz-kurdesz; wskazuje przy tym na trzy strategie realizacji intertekstualizmów: jawne naśladownictwo, aktywną kontynuację i stylizację akceptatywną. Na tym kończy się opis archaizmów rzeczowych.

W następnym podrozdziale omówione zostały archaizmy stylistyczne, które poddano analizie ilościowej, gramatycznej i funkcjonalno-pragmatycznej. Autor rozpoczyna charakterystykę tej grupy archaizmów od podania liczebności poszczególnych klas wraz z przyporządkowaniem do części mowy. Wśród archaizmów stylistycznych (1279 jednostek) najwięcej jest czasowników (494), na kolejnych miejscach plasują się: przymiotniki (202), przysłówki (126), rzeczowniki (120); dalej znalazły się znacznie mniej liczebne grupy, np. modulanty (41), przyimki (16) czy relatory (5). Następnym omawianym zagadnieniem, tak jak w przypdaku opisu archaizmów rzeczowych, jest stopień nasycenia poszczególnych dramatów archaizmami stylistycznymi. Po wyliczeniu jednostek w poszczególnych dramatach, autor ponownie analizuje ich funkcje. Przedstawia typologię dramatów Wyspiańskiego z uwzględnieniem następujących funkcji archaizmów stylistycznych: archaizacji, egzotyzacji, patetyzacji, poetyzacji, rytualizacji. Dalej prezentowane są wykresy ilustrujące zmienność nasycenia archaizmami stylistycznymi dramatów Wyspiańskiego w przekroju diachronicznym. Następnie autor skupia się na językach osobniczych postaci dramatów i podaje zestawienie statystyczne ukazujące liczbę wystąpień archaizmów w kwestiach poszczególnych bohaterów. Dostrzega tu celowy zabieg pisarza, stosowany w celu osiągnięcia zaplanowanego stopnia artystycznej ekspresji. Kolejnym punktem analizy był opis relacji intertekstualnych, tak jak w przypadku archaizmów rzeczowych - wnioski są w tym przypadku podobne. Ostatnim omówionym zagadnieniem były modyfikacje semantyczne archaizmów stylistycznych, wymienia się tu m.in. zabiegi takie jak: przejście od konkretu do abstraktu, przesunięcia znaczeń, nadanie czasownikowi rezultatywnemu znaczenia przyczynowego (i odwrotnie). Po podsumowaniu pierwszej z głównych części swojej monografii, Bobrowski wskazuje jeszcze na perspektywy badawcze, nadmieniając o potrzebie stworzenia komputerowego korpusu tekstów literackich branych pod uwagę $\mathrm{w}$ podobnych badaniach. 
Druga część książki to Słownik archaizmów podzielony na dwie części: A. Słownik tematyczny archaizmów rzeczowych i B. Stownik archaizmów stylistycznych. Zostały tu zestawione wszystkie opracowane przez autora archaizmy wyekscerpowane z materiałów źródłowych i uporządkowane w sposób wcześniej opisany. W części $A$ zachowano klasyfikację tematyczną wraz z podziałem na subklasy i użyto opisu fasetowego. W części $B$ podano opis gramatyczny jednostki, definicję i zacytowano przykłady użycia z dramatów. Autor wskazuje na wiele możliwości praktycznych zastosowań skonstruowanego przez siebie słownika, szczególnie dla osób profesjonalnie zajmujących się twórczością Wyspiańskiego: tłumaczy, inscenizatorów, badaczy.

Książka J. Bobrowskiego Archaizmy leksykalne jako ewokanty dawności kulturowej i językowej w idiolekcie pisarskim Stanisława Wyspiańskiego. Analiza semantyczna i stylistyczno-funkcjonalna szczegółowo bada problem występowania archaizmów w dramatach pisarza. Za pomocą opracowanej przez siebie metodologii, odżegnując się od tradycyjnego podejścia historycznoliterackiego, Bobrowski stara się połączyć badania ilościowe z jakościowymi. Studium należy uznać za wyczerpujące w ramach przyjętych założeń i celów. Jednocześnie chciałoby się wykorzystać metody komputerowe do usprawnienia tego typu badań (o czym autor sam świadomie wspomina) i wprowadzenia dodatkowego punktu widzenia. Ciekawym mogłoby być porównanie np. wyników maszynowego topic modellingu z wnioskami Bobrowkiego albo przeprowadzenie stylomtrycznej analizy wypowiedzi poszczególnych bohaterów dramatów Wyspiańskiego. Wpisuje się to oczywiście we wspomniane przez autora dalsze perspektywy badawcze.

Magdalena Kądzioła

Instytut Języka Polskiego

PAN w Krakowie

magda.kadziola@gmail.com

http://orcid.org/0000-0002-7751-2843 